\title{
Characterization of a Bacteriocin Produced by Lactobacillus plantarum Lp6SH Isolated from "Sha' a", a Maize-Based Traditionally Fermented Beverage from Cameroon
}

\author{
Kaktcham Pierre Marie \\ HEJ Research Institute of Chemistry \\ International Center for Chemical and Biological Sciences (ICCBS) \\ University of Karachi, Karachi-75270, Pakistan \\ $\&$ \\ Laboratory of Biochemistry, Food Science and Nutrition (LABPMAN) \\ Department of Biochemistry, Faculty of Science \\ University of Dschang, PO box 67 Dschang, Cameroon \\ Zambou Ngoufack François (Corresponding author) \\ Laboratory of Biochemistry, Food Science and Nutrition (LABPMAN) \\ Department of Biochemistry, Faculty of Science \\ University of Dschang, PO box 67 Dschang, Cameroon \\ Tel: 237-7781-1129Ｅ-mail: fzambou@yahoo.fr \\ Atiya Abbasi, Fozia Anwar \& Syed Abid Ali \\ HEJ Research Institute of Chemistry \\ International Center for Chemical and Biological Sciences (ICCBS) \\ University of Karachi, Karachi-75270, Pakistan \\ Sieladie Djomne Victor \& Tchouanguep Mbiapo Félicité \\ Laboratory of Biochemistry, Food Science and Nutrition (LABPMAN) \\ Department of Biochemistry, Faculty of Science \\ University of Dschang, PO box 67 Dschang, Cameroon
}

Received: October 24, 2011

Accepted: November 7, $2011 \quad$ Published: April 1, 2012

doi:10.5539/ijb.v4n2p149

URL: http://dx.doi.org/10.5539/ijb.v4n2p149

\begin{abstract}
Lactobacillus plantarum Lp6SH isolated from "Sha'a" a maize-based traditionally fermented beverage from Cameroon, produces a bacteriocin active against Gram-positive and Gram-negative bacteria including Listeria innocua, Staphylococcus aureus, Salmonella typhi, Bacillus cereus, Streptococcus mutans, Escherichia coli, Pseudomonas aeruginosa, Klebsiella pneumonia and Shigella flexneri. Highest bacteriocin production in buffered MRS broth medium was achieved after $6 \mathrm{~h}$ of incubation without agitation. The bacteriocin is of proteinaceous nature as judged by the complete loss of activity after treatment by proteolytic enzymes. Interestingly, this bacteriocin was stable at $121^{\circ} \mathrm{C}$ for $30 \mathrm{~min}$, over a wide range of $\mathrm{pH}(2.0-10.0)$, and when treated with surfactants, organic solvents, EDTA and $\mathrm{NaCl}$. The activity remained after 8 months of storage at $4^{\circ} \mathrm{C}$ and the mode of action against Salmonella typhi ATCC 6539 was bactericidal. The bacteriocin was partially
\end{abstract}


purified using ammonium sulphate precipitation, gel filtration and cation exchange chromatographies. Mass Spectrometry Analysis showed that the Molecular weight of the bacteriocin is $2.340 \mathrm{kDa}$.

Keywords: Sha'a, Lactobacillus plantarum, Bacteriocin, Characterization

\section{Introduction}

Fermentation is one of the oldest and most economical methods of producing and preserving foods (Billings, 1998; Chavan and Kadam, 1989). In developing countries, many traditional foods and beverages are prepared by mean of natural or spontaneous fermentation. In Cameroon, some examples are fermented milk called "Kossam" and a maize-based fermented beverage called "Sha' $a$ ", which is most popular and widely consumed in the western highlands of the country. "Sha' $a$ " is a sweet or low-alcoholic beverage which is viscous, effervescent and whitish-grey to brown coloured. Due to it thick consistency, it is also considered as food by the consumers. As revealed by our preliminary studies, the dominant microorganisms in these beverages are lactic acid bacteria (LAB) and yeasts. During fermentation, many of the LAB produce antimicrobial substances, including bacteriocins. As defined by Klaenhammer (1988), bacteriocins produced by LAB are ribosomally synthesized extracellular small peptides that exhibit bactericidal and bacteriostatic activity against genetically closely related bacteria. Bacteriocins received particular interest due to their potential application in the food industry as natural preservatives, given that they have the advantage of being reliable, non toxic to eukaryotic cells and rapidly digested by proteases within the gastrointestinal tract (Parada et al., 2007). Bacteriocins have always been said to be active only against gram-positive bacteria. However, different researchers described bacteriocins also active against gram-negative bacteria (Ivanova et al., 2000; Kabadjova et al., 2000; Gong et al., 2010). Microbial contamination is still a major problem in local and modern food industries, and more than 250 food-borne diseases have been described. Also, nowadays, there is a worldwide growing demand by consumers for foods containing less or no chemical preservatives. Our preliminary study on the assessment of microbiological quality of "Sha' $a$ " showed that many samples were found contaminated with undesirable microorganisms, whereas other were safe; This stimulated further investigation leading to isolation of LAB with antagonistic activity (Zambou et al., 2007). Despite this, no published paper to the best of our knowledge addressed selection of starter culture for production of "Sha' $a$ " as well as study on bacteriocin production by LAB from this beverage. Whereas there is obvious evidence that LAB strains from different origins could possess antimicrobial activities at different levels. This further stimulates great interest and research on naturally produced antibiotics such as novel bacteriocins from $\mathrm{LAB}$ for their various applications.

This study reports for the first time the partial purification and physico-chemical characterization of a bacteriocin produced by a LAB strain ( $L$ b. plantarum Lp6SH) isolated from "Sha' $a$ ".

\section{Material and Methods}

\subsection{Bacterial strains, media and growth conditions}

The LAB consisted of 21 Lactobacillus spp strains isolated from fermented milk and "Sha' a", previously selected based on their antagonistic activity against each other and some pathogenic indicator bacteria, safety properties and identified as Lactobacillus plantarum (72\%), Lactobacillus rhamnosus (8\%), Lactobacillus fermentum (67\%) and Lactobacillus coprophilus (33\%) based on phenotypic characteristics and rep-PCR fingerprinting. The indicator strain was screened among the 21 mentioned above. These strains were kept in MRS broth plus glycerol (70:30) at $-20^{\circ} \mathrm{C}$ and were sub-cultured twice in MRS broth (Lab M, United Kingdom) for activation prior to experimental use. Agar and soft agar media were prepared by adding respectively 1.5 and $0.75 \%(\mathrm{w} / \mathrm{v})$ granulated agar (Merck) to broth media. For bacteriocin purification, a modified MRS broth medium (mMRS) was prepared by mean of various ingredients (from Oxoid, Merck and Sigma), without beef extract and by replacing ammonium citrate with ammonium sulfate. After adding all medium components, the mixture was dissolved and autoclaved.

\subsection{Screening for bacteriocin producing strains}

This was performed using the triple-agar layer method described by Todorov and Dicks (2005) with the difference that buffered MRS medium ( $0.2 \mathrm{M}$ potassium phosphate buffer, $\mathrm{pH} 7.0)$ was used and no antibiotic was added. Log phase culture of Lactobacillus strains were spotted on buffered MRS agar plates and then recovered with a second layer of the same medium. After incubation at $30^{\circ} \mathrm{C}$ for $48 \mathrm{~h}$ in anaerobiosis, the plates were overlaid with a third layer of soft MRS agar seeded with $15 \mu \mathrm{l}$ of an overnight culture of presumptive LAB indicator strains. The plates were incubated anaerobically at $30^{\circ} \mathrm{C}$ for $24 \mathrm{~h}$ and zone of inhibition surrounding the spots were observed. The most sensitive strain, $L b$. plantarum $3 \mathrm{SH}$ was selected as indicator for the next experiments. 


\subsection{Bacteriocin activity assay}

Cell free supernatants of the selected producer strains were screened for bacteriocin activity by the agar well diffusion assay (AWDA) as described by Schillinger and Lücke (1989). A 15-hour-old culture (2\% v/v) of each Lactobacillus strain was inoculated in buffered MRS broth and incubated anaerobically at $30^{\circ} \mathrm{C}$ for $10 \mathrm{~h}$. The culture was centrifuged at $7000 \mathrm{rpm}$ for $30 \mathrm{~min}$ at $4{ }^{\circ} \mathrm{C}$ and supernatants were collected, then treated at $80{ }^{\circ} \mathrm{C}$ for $10 \mathrm{~min}$ (Todorov and Dicks, 2009). Soft MRS agar seeded with the indicator strain (approximately $10^{7} \mathrm{CFU} / \mathrm{ml}$ ) was dispensed onto pre-poured MRS agar plates. Six millimeter diameter wells were punched in the plates and filled with $50 \mu \mathrm{l}$ of supernatant. After incubation of the plates anaerobically at $30^{\circ} \mathrm{C}$ for $24 \mathrm{~h}$, diameters of zone of inhibition were measured. Bacteriocin titer was determined by the agar spot test as described by Van Reenen et al. (1998) and expressed as arbitrary units (AU/ml). One AU was defined as the reciprocal of the highest serial two-fold dilution showing a clear zone of growth inhibition of the indicator strain. At the end of this set of experiments, Lb. plantarum Lp6SH strain showing the highest activity was selected for the following experiments.

\subsection{Bacteriocin production and protease activity}

A 15-hour-old culture of $\mathrm{Lb}$. plantarum Lp6SH strain was inoculated $(2 \% \mathrm{v} / \mathrm{v})$ into buffered MRS broth and incubated at $30{ }^{\circ} \mathrm{C}$ without agitation. Changes in cell density $\left(\mathrm{O}^{\circ} \mathrm{D}_{600 \mathrm{~nm}}\right)$ were recorded every $2 \mathrm{~h}$ and bacteriocin activity was measured at the same time interval. For the protease activity assay, casein agar plate method (Schumacher and Schill, 1972) was used.

2.5 Sensitivity of bacteriocin to enzymes, $\mathrm{pH}$, temperature, storage, organic solvents, surfactants, NaCl, and EDTA

In this set of experiment, ammonium sulphate precipitate was obtained from $100 \mathrm{ml}$ cell-free supernatant, then dissolved in $50 \mathrm{ml}$ of $25 \mathrm{mM}$ ammonium acetate buffer ( $\mathrm{pH} \mathrm{6.5)} \mathrm{and} \mathrm{used} \mathrm{for} \mathrm{assays.} \mathrm{This} \mathrm{partially} \mathrm{purified}$ bacteriocin was treated with proteolytic enzymes at the ratios 1:50 and 1:100 (Enzyme:Protein, $\mu \mathrm{g} / \mu \mathrm{g}$ ), followed by incubation at $37^{\circ} \mathrm{C}$ for $24 \mathrm{~h}$ on the one hand. On the other hand, $50 \mu \mathrm{l}$ of partially purified bacteriocin was treated with trypsin (Fluka Biochemika), $\alpha$-chymotrypsin (Sigma), Pepsin (Sigma), Proteinase K (Merck), $\alpha$-Amylase (Sigma) and lipase (Sigma) at $0.1 \mathrm{mg} / \mathrm{ml}$ and $1 \mathrm{mg} / \mathrm{ml}$ final concentrations, and incubated at $37^{\circ} \mathrm{C}$ for $2 \mathrm{~h}$. Enzymes reactions were terminated by boiling for $5 \mathrm{~min}$. To test the $\mathrm{pH}$ stability, the partially purified bacteriocin was incubated at $37^{\circ} \mathrm{C}$ for $2 \mathrm{~h}$ at $\mathrm{pH} 2.0$ to 10.0 (at increments of one $\mathrm{pH}$ unit). The effect of temperature on the bacteriocin was tested by heating the partially purified bacteriocin at $100^{\circ} \mathrm{C}$ for 60 and 120 min, and at $121^{\circ} \mathrm{C}$ for 15 and $30 \mathrm{~min}$. In a separate experiment, the effect of surfactant on the bacteriocin activity was determined by adding surfactants (1\% w/v final concentration) consisting of SDS, Tween 80, Tween 20, Triton X-100 and Urea to the lyophilized partially purified bacteriocin. Ethylenediaminetetraacetic acid (EDTA) was added to the sample at $0.1,1,2,3,4$ and 5\% final concentrations, while $\mathrm{NaCl}$ was added respectively at 1,2 , 3, 4, 5, 6 and 7\% final concentrations. The prepared samples were incubated at $37^{\circ} \mathrm{C}$ for $5 \mathrm{~h}$. The effect of organic solvents was tested by adding $5 \%(\mathrm{v} / \mathrm{v})$ solution of methanol, ethanol, isopropanol, acetone, chloroform and acetonitrile to the samples followed by incubation at $37^{\circ} \mathrm{C}$ for $2 \mathrm{~h}$. Finally, the sample was kept at $4{ }^{\circ} \mathrm{C}$ to evaluate the effect of storage. Untreated sample and sterile MRS broth treated with enzymes or chemicals served as controls; after each treatment, the residual activity was determined by AWDA. All experiments were performed in triplicate.

\subsection{Mode of bacteriocin action}

Strain Lp6SH was anaerobically cultured in buffered MRS broth for $6 \mathrm{~h}$ at $30^{\circ} \mathrm{C}$ and the culture free supernatant was obtained and treated as previously described. Twenty milliliter of this supernatant (800 AU/ml) was added to $100 \mathrm{ml}$ of a 3-hour growing culture of Salmonella enterica subsp. enterica serovare Typhi (or Salmonella Typhi) strain ATCC 6539 in nutrient broth at $37^{\circ} \mathrm{C}$ Changes in cell density were recorded at $600 \mathrm{~nm}$ at 1-hour interval for $8 \mathrm{~h}$, and the number of viable cells (CFU) was determined by plating the samples on Salmonella-Shigella agar $(1.5 \% \mathrm{w} / \mathrm{v})$ followed by incubation at $37^{\circ} \mathrm{C}$ for $24 \mathrm{~h}$.

\subsection{Partial Purification of the bacteriocin}

The bacteriocin was purified from 1 litre of mMRS broth culture of $L b$. plantarum Lp6SH strain incubated at $30{ }^{\circ} \mathrm{C}$ for $6 \mathrm{~h}$, without agitation. The culture was centrifuged $\left(7000 \mathrm{rpm}, 30 \mathrm{~min}, 4^{\circ} \mathrm{C}\right)$ and the cell-free neutralized supernatant obtained was treated at $80^{\circ} \mathrm{C}$ for $10 \mathrm{~min}$, and then precipitated with ammonium sulfate (60\% saturation). The mixture was stirred at $4^{\circ} \mathrm{C}$ for at least $4 \mathrm{~h}$ and then kept at $4^{\circ} \mathrm{C}$ for overnight. The precipitate was collected by centrifugation $\left(10000 \mathrm{rpm}, 15 \mathrm{~min}, 4^{\circ} \mathrm{C}\right)$, dissolved in one tenth volume of $25 \mathrm{mM}$ ammonium acetate buffer $(\mathrm{pH} 6.5)$ and loaded $(10 \mathrm{ml})$ on a sephadex G-25 (Pharmacia, Uppsala, Sweden) 
column $(30 \mathrm{~cm} \times 2.5 \mathrm{~cm})$ equilibrated with $0.1 \mathrm{M}$ acetic acid solution at a flow rate of $16 \mathrm{ml} / \mathrm{h}$. Fractions of $4 \mathrm{ml}$ were collected and the antimicrobial activity was determined by the AWDA. Active fractions were pooled and loaded on a CM-cellulose (microgranular form, Sigma-Aldrich) column $(30 \mathrm{~cm} \times 1.5 \mathrm{~cm})$ pre-equilibrated and washed with sterile deionised water. The absorbed proteins were eluted with a stepwise gradient of $(0-1 \mathrm{M})$ $\mathrm{NaCl}$ at a flow rate of $16 \mathrm{ml} / \mathrm{h}$. Fractions of $4 \mathrm{ml}$ were collected, the absorbance recorded at $280 \mathrm{~nm}$ and the antimicrobial activity was determined.

\subsection{Sodium dodecyl sulphate-polyacrylamide gel electrophoresis (SDS-PAGE)}

The pooled active fractions from gel filtration chromatography was analyzed by Tris-glycine SDS-PAGE (Laemmli, 1970) under reducing conditions and on a Bio-Rad Electrophoresis system, using 15\% separation gel and $4 \%$ stacking gel (30\% acrylamide, $0.8 \%$ bisacrylamide). Bovine Serum Albumine (66 kDa) and Lysozyme $(14.3 \mathrm{kDa})$ were used as molecular mass markers. Electrophoresis was run at a constant voltage $(150 \mathrm{~V})$. The gel was cut into 2 halves; one half was visualized by Coomassie Brilliant Blue R-250 and silver staining. The other half was placed in a MRS agar plate and overlaid with Lactobacillus plantarum 3SH strain seeded in soft MRS agar, in order to determine the authenticity of the active bacteriocin.

\subsection{Mass Spectrometry Analysis}

Pooled Active peptide fraction from CM-Cellulose Chromatography was analysed by matrix-assisted laser desorption/ionisation time-of-flight mass spectrometry (MALDI-TOF/ MS) (Ultraflex III TOF/TOF, Bruker, Daltonics, Bremen, Germany). A solution of $10 \mathrm{mg} / \mathrm{ml}$ of $\alpha$-cyano-4-hydroxycinnamic acid was used as saturated matrix. The sample was diluted in 50\% Acetonitrile/0,1\%TFA solution and then, $0.5 \mu 1$ of the diluted sample was mixed with an equal volume of saturated matrix solution. The mixture was spotted on the target of a $16 \times 24$ MALDI plate and left to dry at room temperature for at least $15 \mathrm{~min}$. The analyzer operated in positive ion mode, Desorption/Ionization was realized by laser irradiation using nitrogen laser $(\lambda=337 \mathrm{~nm})$ and the spectrum was acquired in reflectron mode.

\subsection{Spectrum of inhibitory activity}

The antibacterial activities of the ammonium sulfate-precipitated samples were tested against Gram-positive and Gram-negative bacteria. The indicator strains ( $0.5 \mathrm{Mac}$ Farland suspensions) were inoculated in the appropriate soft agar media and the antibacterial activities were determined by AWDA previously described. All experiments were conducted in triplicate.

\section{Results and Discussion}

\subsection{Screening for bacteriocin producing strains}

Using combination of Triple-Agar layer method and AWDA, 12 (57.1\%) out of the 21 strains tested were found to be bacteriocin producers. The strain $L$ b. plantarum $6 \mathrm{~S}$, whose supernatant exhibited highest and broad activity, was selected for next experiments. It was designated as Lactobacillus plantarum Lp6SH and the bacteriocin produced was termed bacteriocin Lp6SH. Likewise, strain Lactobacillus plantarum 3S, selected as most sensitive was designated as Lactobacillus plantarum $3 \mathrm{SH}$.

\subsection{Bacteriocin production and protease activity}

The strain Lp6SH showed a typical sigmoidal growth response. Maximum activity was recorded at early stationary phase and decreases afterwards (figure 1). Results of the protease activity showed that extracellular proteases are produced during the stationary phase (data not shown). Thus, the decrease of bacteriocin production from the stationary phase can be ascribed to destruction by the proteases produced. Detection of bacteriocin production after $2 \mathrm{~h}$ of growth followed by maximum production at early stationary growth phase may suggest that the peptide is secreted as a primary metabolite. This is in accordance with results obtained for other bacteriocins from Lb. plantarum so far described (Van Reenen et al., 1998; Todorov and Dicks, 2004; Todorov et al., 2004; Todorov et al., 2011).

\subsection{Sensitivity of bacteriocin to enzymes, $\mathrm{pH}$, heat, storage, organic solvents, surfactants $\mathrm{NaCl}$, and EDTA}

Complete inactivation was observed when partially purified bacteriocin Lp6SH was treated by trypsin, $\alpha$-chymotrypsin and pepsin, thus confirming its proteinaceous nature. Treatment with $\alpha$-Amylase and lipase did not affect the antimicrobial activity, suggesting that the bacteriocin is not attached to a carbohydrate or lipid moiety (Table 1). Similar results have been reported for other bacteriocins of Lb. plantarum (De Vuyst and Vandamme, 1994; Todorov et al., 2004). Bacteriocin Lp6SH was found to be stable in the pH range 2.0 to 10.0. The bacteriocin was resistant to heat. Remarkably, $80 \%$ of the activity could still be recorded against $L b$. plantarum strain $3 \mathrm{SH}$ after $30 \mathrm{~min}$ at $121^{\circ} \mathrm{C}$. Full bacteriocin activity was retained upon storage at $4{ }^{\circ} \mathrm{C}$ up to 8 
months (Table 1). Partially purified bacteriocin was not sensitive to $\mathrm{NaCl}$, Tween 80 , Tween 20 and Triton X-100. However, SDS and Urea reduced bacteriocin activity. When EDTA was added to the partially purified bacteriocin, the antimicrobial activity of the mixture was stronger than EDTA or bacteriocin tested alones (Table 1). Many other bacteriocins produced by $L b$. plantarum strains were found to be stable to the above factors. However, plantaricin C19 produced by Lb. plantarum C19 lost its activity after treatment with SDS or Triton X-100 (Atrih, et al., 2001).

\subsection{Mode of bacteriocin Lp6SH action}

The addition of crude bacteriocin to a 3-hour-old culture of Salmonella Typhi ATCC 6539 strain caused a significant decrease in cellular viability (from $3.8 \times 10^{6} \mathrm{CFU} / \mathrm{ml}$ to $1.9 \times 10^{4} \mathrm{CFU} / \mathrm{ml}$ within $5 \mathrm{~h}$ ) during the $8 \mathrm{~h}$, while the viability of untreated cells significantly increases in comparison (Figure 2). Killing of the cells started within $1 \mathrm{~h}$ after the addition. These results suggest that the mode of activity of bacteriocin Lp6SH is bactericidal.

\subsection{Partial Purification of the bacteriocin}

During the purification protocol, the proteins precipitated by ammonium sulfate presented activity (409600 $\mathrm{AU} / \mathrm{ml}$ ) against $L$ b. plantarum $3 \mathrm{SH}$. When the ammonium sulfate precipitate was subjected to gel filtration on a sephadex G-25 column, $12800 \mathrm{AU} / \mathrm{ml}$ activity was recorded. During further purification on CM-Cellulose column, $0.6 \mathrm{M} \mathrm{NaCl}$ removed the absorbed bacteriocin from the column and $400 \mathrm{AU} / \mathrm{ml}$ was obtained. A protocol similar to this one but without gel filtration was used for purification of diploccocin and other protocols have been also used by several authors for purification of bacteriocins produced by other $L b$. plantarum strains (Todorov et al., 1999; Gong et al., 2010).

\subsection{SDS-PAGE and mass spectrometry}

No protein bands were detected by SDS- PAGE analysis. However, bacteriocin activity was detected in the gel after the overlay assay (Figure 3). This result suggests that the concentration of the active peptide was low as also found for Lb. acidophilus n.v. Er 317/402 strain narine (Mkrtchyan et al., 2010). MALDI-TOF/MS analysis revealed that the molecular weight of the bacteriocin is $2.340 \mathrm{kDa}$.

\subsection{Spectrum of inhibitory activity}

Bacteriocin Lp6SH inhibited the growth of a $\mathrm{Lb}$. plantarum strain as well as a number of food spoilage and foodborne pathogenic bacteria including species of the genera Listeria, Streptococcus, Shigella, Bacillus, Staphylococcus, Escherichia, Salmonella, Pseudomonas and Klebsiella. However, No activity was detected against many other Lactobacilli as well as an Enterococcus faecium strains tested (Table 2), suggesting that $L b$. plantarum Lp6SH strain could be easily associated with other LAB starter cultures. More interestingly, Multi-Drug Resistant (MDR) strains of Staphylococcus aureus and Escherichia coli were inhibited. Bacteriocin Lp6SH is hence being part of the few ones produced by Lb. plantarum strains that inhibited the growth of Gram-negative bacteria (Todorov et al., 2007; Gong et al., 2010). But it could be particular in that it is active against E. coli, P. aeruginosa, S. Typhi and K. pneumoniae (Table 2). Inhibition of Listeria spp by bacteriocin Lp6SH suggests that it might belong to class IIa bacteriocins.

\section{Conclusion}

The bacteriocin produced by $L b$. plantarum Lp6SH strain was partially purified. It showed high stability to $\mathrm{pH}$, heat, surfactants, organic solvents and $\mathrm{NaCl}$. In addition, Bacteriocin Lp6SH showed a broad antibacterial spectrum. $L b$. plantarum Lp6SH may be used as protective stater culture to enhance the safety of spontaneously fermented foods.

\section{Acknowledgements}

This study received the financial support of the Third world Academy of Science (TWAS) through the TWAS Fellowship for Research and Advanced Training (FR number: 3240224114) awarded to Mr Kaktcham. The authors are also thankful to ICCBS, University of Karachi-Pakistan for the Laboratory facilities offered.

\section{References}

Atrih, A., Rekhif, N., Moir, A. J. G., Lebrihi, A., \& Lefebvre G. (2001). Mode of action, purification and amino acid sequence of plantaricin C19, an anti-Listeria bacteriocin produced by Lactobacillus plantarum C19. International Journal of Food Microbiology, 68, 93-109. http://dx.doi.org/10.1016/S0168-1605(01)00482-2

Billings, T. (1998). On fermented foods. [Online] Available: http://www.living-foods.com/articles/fermented.html (June 8, 2011).

Chavan, J. K., \& Kadam, S. S. (1989). Critical reviews in food science and nutrition. Food Science, 28, 348-400. 
De Vuyst, L. \& Vandamme E. (1994). Bacteriocins of lactic acid bacteria (p. 539). Blackie London, United Kingdom.

Gong, H. S., Meng, X. C., \& Wang, H. (2010). Plantaricin MG active against Gram-negative bacteria produced by Lactobacillus plantarum KLDS1.0391 isolated from "Jiaoke", a traditional fermented cream from China. Food control, 21: 89 - 96. http://dx.doi.org/10.1016/j.foodcont.2009.04.005

Ivanova, I., Kabadjova, P., Pantev, A., Danova, S., \& Dousset, X. (2000). Detection, purification and partial characterization of a novel bacteriocin substance produced by Lactococcus lactis susp. lactis B14 isolated from boza-Bulgarian traditional cereal beverage. Biocatal—Vestnik Moskov univ Kimia, 41, 47-53.

Kabadjova, P., Gotcheva, I., Ivanova, I., \& Dousset, X. (2000). Investigation of bacteriocin activity of lactic acid bacteria isolated from boza. Biotechnology and Biotechnological Equipment, 14, 56-59.

Klaenhammer T. R. (1988). Bacteriocins of lactic acid bacteria. Biochimie, 70(3), 337-349. http://dx.doi.org/10.1016/0300-9084(88)90206-4

Laemmli, U. K. (1970). Cleavage of structural proteins during the assembly of the head of bacteriophage T4. Nature, 227, 680. http://dx.doi.org/10.1038/227680a0

Mkrtchyan, H., Gibbons, S., Heidelberger, S., Zloh, M., \& Limaki, H. K. (2010). Purification, characterisation and identification of acidocin LCHV, an antimicrobial peptide produced by Lactobacillus acidophilus n.v. Er 317/402 strain Narine. International Journal of Antimicrobial Agents, 35, 255-260. http://dx.doi.org/10.1016/j.ijantimicag.2009.11.017

Parada, J. L., Caron, C. R., Medeiros, A. B. P., \& Soccol, C. R. (2007). Bacteriocins from Lactic Acid Bacteria: Purification, Properties and use as Biopreservatives. Brazilian Archive of Biology and Technology, 50(3), 521-542. http://dx.doi.org/10.1590/S1516-89132007000300018

Schillinger, U., \& Lücke, F. K. (1989). Antibacterial activity of Lactobacillus sake isolated from meat. Applied and Environmental Microbiology, 55(8), 1901-1906.

Schumacher, G. F., \& Schill, W. B. (1972). Radial diffusion in gel for micro determination of enzymes. II plasmogen activator, elastase, and nonspecific proteases. Anal Biochem, 48, 9-26. characterization of a novel antibacterial substance produced by Lactobacillus plantarum ST31 isolated from sourdough. International Journal of Food Microbiology, 48: 167-177.

Todorov S. D., Prévost, H., Lebois, M., Dousset, X., Le Blanc, J. G., \& Franco, B. D. G. M. (2011). Bacteriocinogenic Lactobacillus plantarum ST16Pa isolated from papaya (Carica papaya) - From isolation to application: Characterization of a bacteriocin. Food Research International, 44(5), 1351-1363. http://dx.doi:10.1016/j.foodres.2011.01.027

Todorov, S. D., \& Dicks L. M. T. (2005). Lactobacillus plantarum isolated from molasses produces bacteriocins active against Gram-negative bacteria. Enzyme Microb. Technol, 36, 318-326. http://dx.doi.org/10.1016/j.enzmictec.2004.09.009

Todorov, S. D., \& Dicks, L. M. T. (2004). Influence of growth conditions on the production of a bacteriocin by Lactococcus lactis subsp. lactis ST34BR, a strain isolated from barley beer. Journal of Basic Microbiology, 44(4), 305-316. http://dx.doi.org/10.1002/jobm.200410413

Todorov, S. D., \& Dicks, L. M. T. (2009). Bacteriocin production by Pediococcus pentosaceus isolated from marula (Scerocarya birrea). International Journal of Food Microbiology, 132, 117-126. http://dx.doi.org/10.1016/j.ijfoodmicro.2009.04.010

Todorov, S. D., Nyati, H., Meincken, M., \& Dicks, L. M. T. (2007). Partial characterization of bacteriocin AMA-K, produced by Lactobacillus plantarum AMA-K isolated from naturally fermented milk from Zimbabwe. Food Control, 18(6), 656-664. http://dx.doi.org/10.1016/j.foodcont.2006.03.003

Todorov, S. D., Van Reenen, C. A., \& Dicks, L. M. T. (2004). Optimization of bacteriocin production by Lactobacillus plantarum ST13BR, a strain isolated from barley beer. Journal of General and Applied Microbiology, 50, 149-157. http://dx.doi.org/10.2323/jgam.50.149

Van Reenen, C. A., Dicks, L. M. T., \& Chikindas, M. L. (1998). Isolation, purification and partial characterization of plantaricin 423, a bacteriocin produced by Lactobacillus plantarum. Journal of Applied Microbiology, 84(6), 1131-1137. http://dx.doi.org/10.1046/j.1365-2672.1998.00451.x

Zambou N. F., El Hoda, N., Fonteh, A. F., Moundipa, F. P., Mbiapo, T. F., \& El-Soda, M. (2007). Biochemical properties of some thermophilic lactic acid bacteria from traditional fermented milk relevant to their properties 
as starter culture. Biotechnology, 6(1), 14-21. http://dx.doi.org/10.3923/biotech.2007.14.21

Table 1. Effect of enzymes, $\mathrm{pH}$, heat, storage, organic solvents, surfactants, Urea, $\mathrm{NaCl}$ and EDTA on Bacteriocin Lp6SH activity

\begin{tabular}{|c|c|c|}
\hline Treatment & & $\begin{array}{l}\text { Inhibition Zone } \\
(\mathbf{m m})^{\mathrm{a}}\end{array}$ \\
\hline \multicolumn{3}{|l|}{ Enzymes } \\
\hline & Without Enzymes & 15.0 \\
\hline & $\begin{array}{l}\text { Trypsin, Pepsin , } \alpha \text {-Chymotrypsin }(1: 50 \& 1: 100 \mu \mathrm{g} / \mu \mathrm{g} \\
\text { protein) }\end{array}$ & - \\
\hline & $\begin{array}{l}\text { Trypsin, Pepsin, } \alpha \text {-Chymotrypsin, Proteinase K }(0.1 \& 1 \\
\mathrm{mg} / \mathrm{ml})\end{array}$ & - \\
\hline & $\alpha$-Amylase, Lipase $(0.1 \& 1 \mathrm{mg} / \mathrm{ml})$ & 14.5 \\
\hline & Lysozyme $(0.1 \& 1 \mathrm{mg} / \mathrm{ml})$ & 15.0 \\
\hline \multicolumn{3}{|l|}{ pH } \\
\hline & $2-8$ & 15.0 \\
\hline & 10 & 14.5 \\
\hline \multicolumn{3}{|c|}{ Temperature } \\
\hline & $100^{\circ} \mathrm{C}$ for $60 \mathrm{~min}$ & 15.0 \\
\hline & $100{ }^{\circ} \mathrm{C}$ for $120 \mathrm{~min}$ & 14.0 \\
\hline & $121{ }^{\circ} \mathrm{C}$ for $15 \mathrm{~min}$ & 14.0 \\
\hline & $121^{\circ} \mathrm{C}$ for $30 \mathrm{~min}$ & 12.0 \\
\hline \multicolumn{3}{|l|}{ Storage } \\
\hline & $4^{\circ} \mathrm{C}$ for at least 8 months & 15.0 \\
\hline \multicolumn{3}{|c|}{ Organic solvents } \\
\hline & Ethanol, Methanol, Acetone & 15.0 \\
\hline & Isopropanol, Acetonitrile, Chloroform & 14.5 \\
\hline \multicolumn{3}{|c|}{ Surfactants / Chemicals } \\
\hline & SDS $(1 \% \mathrm{w} / \mathrm{v})$ & 9.0 \\
\hline & Tween 80, Tween 20, Triton X-100 (1\% w/v) & 15.0 \\
\hline & Urea $(1 \% \mathrm{w} / \mathrm{v})$ & 14.5 \\
\hline & $\mathrm{NaCl}(1-7 \% \mathrm{w} / \mathrm{v})$ & 15.0 \\
\hline & EDTA $(0.1 \% \mathrm{w} / \mathrm{v})$ Without bacteriocin & 12.0 \\
\hline & EDTA $(0.1 \% \mathrm{w} / \mathrm{v})$ With bacteriocin & 16.0 \\
\hline & EDTA $(2 \% \mathrm{w} / \mathrm{v})$ Without bacteriocin & 23.0 \\
\hline & EDTA $(2 \% \mathrm{w} / \mathrm{v})$ With bacteriocin & 26.0 \\
\hline & EDTA $(5 \% \mathrm{w} / \mathrm{v})$ Without bacteriocin & 27.0 \\
\hline & EDTA $(5 \% \mathrm{w} / \mathrm{v})$ With bacteriocin & 31.0 \\
\hline
\end{tabular}

a: Mean Inhibition Zone Diameters, including the diameter of the wells $(6 \mathrm{~mm})$. "-": no inhibitory zone was observed. 
Table 2. Spectrum of antibacterial activity of bacteriocin Lp6SH

\begin{tabular}{|c|c|c|c|c|}
\hline \multirow[t]{2}{*}{ Indicator strains } & \multirow[t]{2}{*}{ Source } & \multirow{2}{*}{$\begin{array}{c}\text { Growth } \\
\text { conditions }\end{array}$} & \multicolumn{2}{|c|}{ Bacteriocin Activity (mm) } \\
\hline & & & NCFS & ASP \\
\hline \multicolumn{5}{|l|}{ lactic acid bacteria } \\
\hline Lb. Plantarum $3 S H$ & Our isolate & $\mathrm{MRS}^{\mathrm{c}}, 30^{\circ} \mathrm{C}$ & 16 & 21 \\
\hline Lb plantarum $9 S$ & Our isolate & MRS, $30^{\circ} \mathrm{C}$ & - & - \\
\hline Lb. Plantarum $29 \mathrm{~V}$ & Our collection & $\mathrm{MRS}, 30^{\circ} \mathrm{C}$ & - & - \\
\hline Lb. Rhamnosus $18 S$ & Our isolate & MRS, $30^{\circ} \mathrm{C}$ & - & - \\
\hline Lb. Rhamnosus $1 K$ & Our isolate & $\mathrm{MRS}, 30^{\circ} \mathrm{C}$ & - & - \\
\hline Lb. Fermentum $2 K$ & Our isolate & $\mathrm{MRS}, 30^{\circ} \mathrm{C}$ & - & - \\
\hline Enterococcus faecium & $\mathrm{DSM}^{\mathrm{a}} 13596$ & $\mathrm{BHI}^{\mathrm{d}}, 37^{\circ} \mathrm{C}$ & - & - \\
\hline \multicolumn{5}{|l|}{$\begin{array}{l}\text { Gram positive pathogenic } \\
\text { bacteria }\end{array}$} \\
\hline Listeria innocua & ATCC $^{\mathrm{b}} 33090$ & $\mathrm{BHI}, 37^{\circ} \mathrm{C}$ & 15 & 19 \\
\hline Staphylococcus aureus & ATCC 25923 & $\mathrm{BHI}, 37^{\circ} \mathrm{C}$ & 17 & 22 \\
\hline Staphylococcus aureus (MDR) & Clinical isolate & $\mathrm{BHI}, 37^{\circ} \mathrm{C}$ & 11 & 17 \\
\hline Bacillus cereus & ATCC 11778 & $\mathrm{BHI}, 37^{\circ} \mathrm{C}$ & 13 & 18 \\
\hline Streptococcus mutans & DSM 20523 & $\mathrm{BHI}, 37^{\circ} \mathrm{C}$ & 15 & 22 \\
\hline \multicolumn{5}{|l|}{$\begin{array}{l}\text { Gram negative pathogenic } \\
\text { bacteria }\end{array}$} \\
\hline Escherichia coli & ATCC 13706 & $\mathrm{BHI}, 37^{\circ} \mathrm{C}$ & 13 & 18 \\
\hline Escherichia coli (MDR) & Clinical isolate & $\mathrm{BHI}, 37^{\circ} \mathrm{C}$ & - & 8 \\
\hline Salmonella Typhi & ATCC 6539 & $\mathrm{NB}^{\mathrm{e}}, 37^{\circ} \mathrm{C}$ & 16 & 24 \\
\hline Pseudomonas aeruginosa & ATCC 9027 & $\mathrm{BHI}, 37^{\circ} \mathrm{C}$ & 15 & 20 \\
\hline Pseudomonas aeruginosa & ATCC 27853 & $\mathrm{BHI}, 37^{\circ} \mathrm{C}$ & 13 & 17 \\
\hline Klebsiella pneumoniae & Clinical isolate & $\mathrm{BHI}, 37^{\circ} \mathrm{C}$ & 15 & 18 \\
\hline Shigella flexneri & Clinical isolate & $\mathrm{NB}, 37^{\circ} \mathrm{C}$ & 12 & 18 \\
\hline
\end{tabular}

*: Inhibition zone Diameters are means of triplicates; Wells $(6 \mathrm{~mm}$ in diameter) were filled with $100 \mu \mathrm{l}$ of supernatant or $60 \%$ ammonium sulfate precipitated samples. "-"no inhibition. MDR = Multi Drug Resistant. NCFS $=$ Neutralized Cell-free supernatant; ASP $=$ Ammonium Sulfate Precipitate.

a: DSM: Deutsche Sammlung von Mikroorganismen und Zellkulturen GmbH, Braunschweig, Germany

b: ATCC: American Type Culture Collection, Manassas, VA, USA

c: de Man, Rogosa and Sharpe

d: Brain Heart Infusion

e: Nutrient Broth 


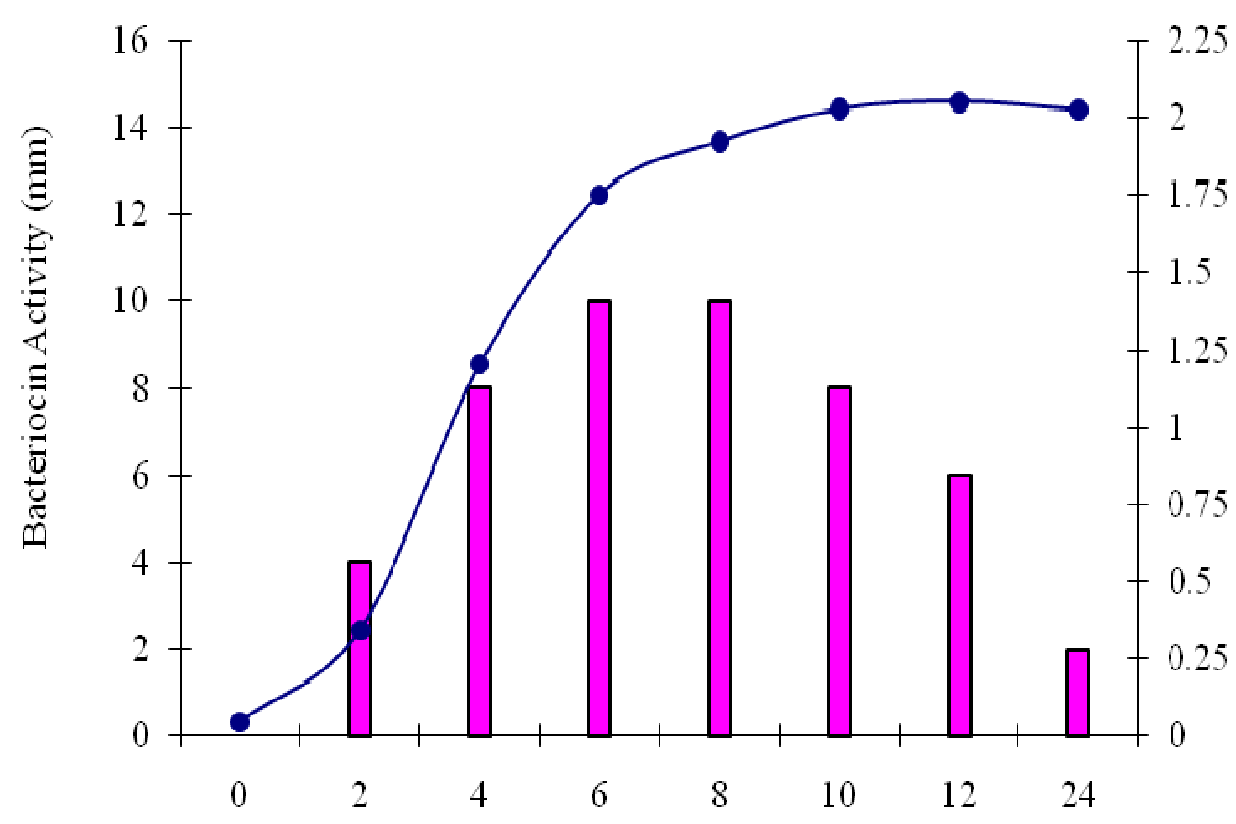

Time (h)

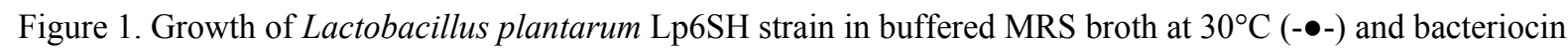
production (-m-)

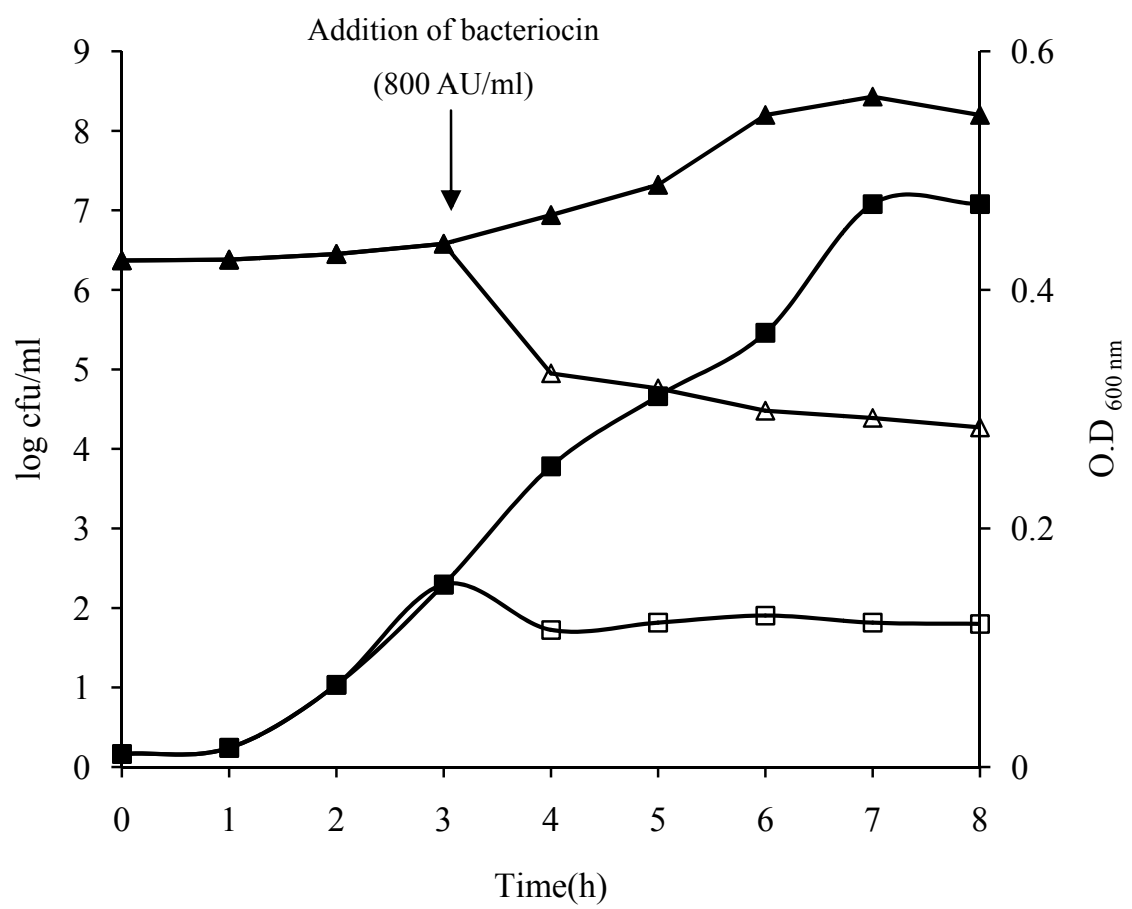

Figure 2. Effect of bacteriocin Lp6SH on the growth of salmonella Typhi ATCC 6539; Optical Density (O.D) in the absence (--) and presence (- $\square-)$ of bacteriocin; Viable cell counts in the absence (- $\boldsymbol{\Delta}_{-}$) and presence (- $\Delta-$-) of bacteriocin 


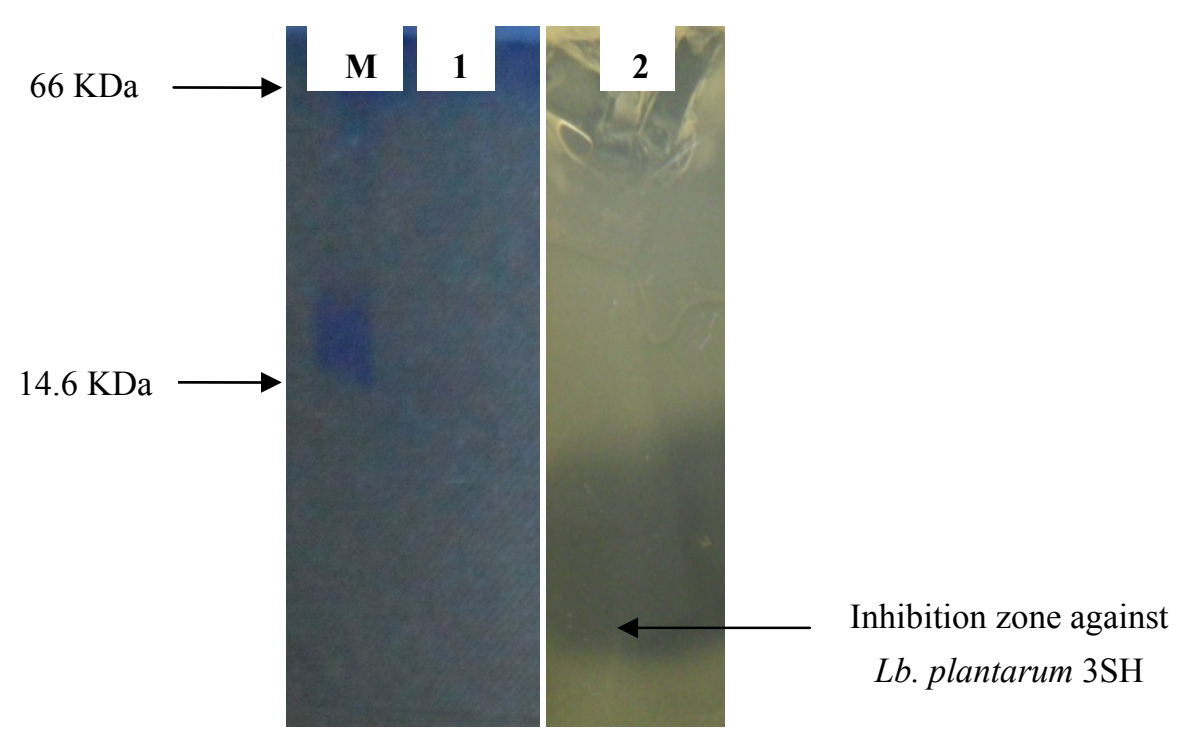

Figure 3. SDS-PAGE of bacteriocin Lp6SH. Lane M: Molecular weight markers (BSA and Lysozyme)

Lanes 1 and 2: Bac Lp6SH (Gel filtration active fraction). Inhibition zone indicates the position of the active peptide band. The gel was overlaid with viable cells of $L b$. plantarum $3 \mathrm{SH}$ inoculated in MRS soft agar. Incubation was performed anaerobically at $30^{\circ} \mathrm{C}$ for $24 \mathrm{~h}$ 